\title{
Medical Students Perception of Current Undergraduate Anatomy Teaching
}

\author{
Percepción de Estudiantes de Medicina de la Enseñanza Actual de Anatomía en el Pregrado
}

\author{
Raed Tayyem $^{1}$; Haitham Qandeel ${ }^{1}$; Ghaith Qsous²; Darwish Badran³ \& Kamal Bani-Hani'
}

TAYYEM, R.; QANDEEL, H.; QSOUS, G.; BADRAN, D. \& BANI-HANI, K. Medical students perception of current undergraduate anatomy teaching. Int. J. Morphol., 37(3):825-829, 2019.

SUMMARY: Anatomy it is one of the basic sciences in medical schools where it takes part in the first 3 years of the teaching curriculum. Aim of this survey is to explore the perception of medical students in undergraduate level to anatomy teaching in different medical schools and identify the weakness points and area which could help in improvement the teaching process with better outcomes. This is a prospective multi center study, conducted between May 2018 to August 2018 on 313 medical students in their internship year and 6th year of medical school. Questionnaire was sent to students taking into consideration the importance of protecting the students privacy. The questionnaire was developed after thorough review of the literature and its items were chosen following consultation with senior medical colleagues and educationalists. The questionnaire was created using 8-item liker scale so as to enforce an answer and avoid neutral answer. Out of 313 students: 212 were female students $(67.7 \%)$ and $101(32.3 \%)$ were males. 123 students (39.3\%) favored the combination of cadaveric dissection and multimedia as best teaching methods. Most students thought that the classic methods of teaching may not be very helpful in understanding the radiological images and laparoscopic intra-operative views. Most students suggested that engaging surgeons in anatomy teaching may improve their clinical knowledge in Anatomy. Our results showed that the approach of teaching could be improved by including combination of multiple techniques specially cadaveric dissection and multimedia sessions. The results also encouraged medical schools to utilize surgeons more often to teach anatomy.

KEY WORDS: Anatomy teaching; Medical student; Surgeon; Student's perception of teaching.

\section{INTRODUCTION}

Anatomy knowledge is very important in the career of any surgeon, which helps in diagnosis, interpret clinical images, treatment and how to operate. Poor knowledge of anatomy reflects negatively on patients and their outcomes. Therefore, better knowledge of anatomy by developing effective modalities for teaching anatomy can lead to safer practice of medicine (Estai \& Bunt, 2016; Iqbal, 2016; Sbayeh et al., 2016; Choi-Lundberg et al., 2016; Ghosh, 2017).

There are varieties of strategies for teaching anatomy such as theoretical lectures, cadaveric dissection, multimedia and 3D models. Every model could have its advantages and disadvantages. There is much debate about suitable methods of delivering anatomical knowledge. The faculty responsible for delivering anatomy teaching sessions are mainly by nonsurgeons in the first three years which also could have an effect on the way of delivering and explaining the information to students (Peterson \& Mlynarczyk, 2016; Shiozawa et al., 2017; Bandyopadhyay \& Biswas, 2017; Alhassan \& Majeed, 2018; Eppler et al., 2018).

Medicine is the compassionate art of healing through a detailed understanding of the tissues and structures of the body. Therefore, we will explore the views of medical students and newly graduated doctors regarding the best method for teaching anatomy (Turney, 2007; Kerby et al., 2011).

\section{MATERIAL AND METHOD}

A prospective multi-centric study was conducted on 313 medical student from May 2018 to August 2018.

\footnotetext{
${ }^{1}$ General surgery Department, Faculty of Medicine, Hashemite University, Al-Zarqa, Jordan.

${ }^{2}$ General surgery Department, King Hussein Cancer Center, Amman, Jordan.

${ }^{3}$ Department of Anatomy, Faculty of Medicine, Hashemite University, Al-Zarqa, Jordan.
} 
Students included in this study were either 6th year medical students or newly graduated students doing their internship year. Students eligible for inclusion were Jordanian universities undergraduates.

The questionnaire was developed after thorough review of the literature and its items were chosen following consultation with senior medical colleagues and educationalists.

The aim of the questionnaire was to evaluate our undergraduate anatomy teaching and explore the best method to deliver anatomy and maximize the benefit from the current teaching methods. The study examined the relationship between our current methods of anatomy teaching and students ability of interpreting radiological pictures and endoscopic views. In addition, the study assessed students satisfaction from current methods in teaching anatomy and their opinion regarding being taught anatomy by surgeons.

The questionnaire was created using 8-item liker scale so as to enforce an answer and avoid neutral answer. This questionnaire was done taking in mind importance of protection the students privacy. Data were collated and analyzed from electronic records.

Questionnaires was distributed to the eligible medical students electronically via Google forms (Tayyem, 2018).

Data were collated and analyzed from electronic records using SPSS software.

\section{RESULTS}

The 313 Medical students from 4 registered medical schools (University of Jordan, Jordanian University of Science and Technology, Hashemite University and Mutah University) completed the questionnaire. 251 participants $(80.2 \%)$ were 6th year medical students, and the remainder $(19.8 \%)$ were internship students. 212 students $(67.7 \%)$ were a females and $101(32.3 \%)$ were males.

Regarding the methods of teaching anatomy, 153 students $(48.9 \%)$ said that they got their anatomy teaching via lectures and cadaveric dissection, whereas 60 students $(19.2 \%)$ said that they were taught by lectures, cadaveric dissection, and multimedia. 44 students $(14.1 \%)$ mentioned that they were taught anatomy just by lectures (Fig. 1).

Regarding the student opinion about the best method of teaching anatomy, 123 students (39.3\%) supported the combination of (cadaveric dissection and multimedia), whereas $43(13.7 \%)$ and $42(13.4 \%)$ respectively thought that multimedia alone and cadaveric dissection alone is best. Combination of (lectures, multimedia, and cadaveric dissection ) was chosen by 41 students (13.1\%) (Fig. 2).

Examination methods of anatomy were varying between (MCQ and on cadaver examination) $35.8 \%$ and MCQ alone $34.5 \%$. Students opinion regarding best methods of examining anatomy also varied as the following: 75 students (24\%) preferred cadaver method only, 41 students

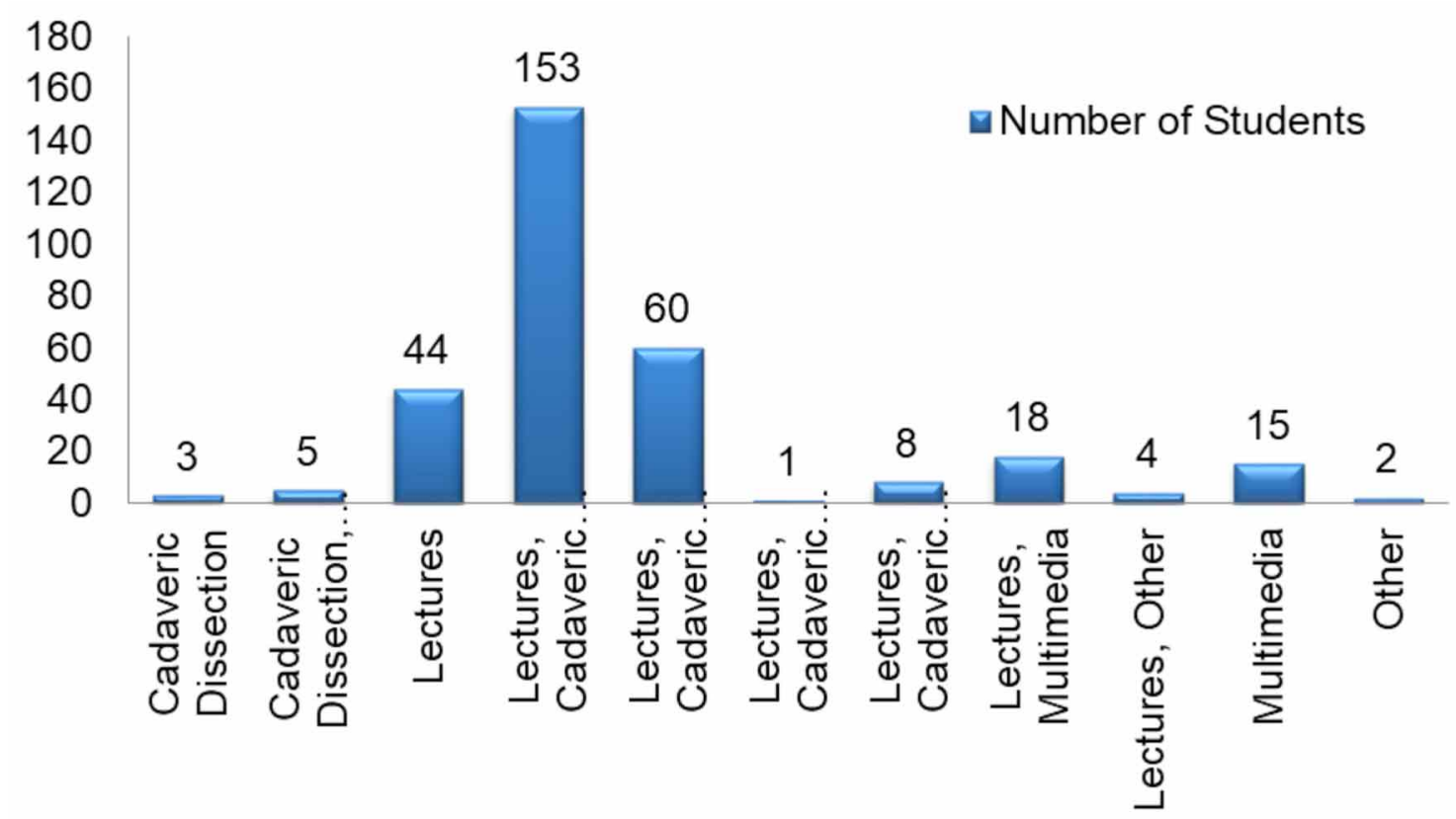

Fig. 1. How your anatomy teaching was delivered? 


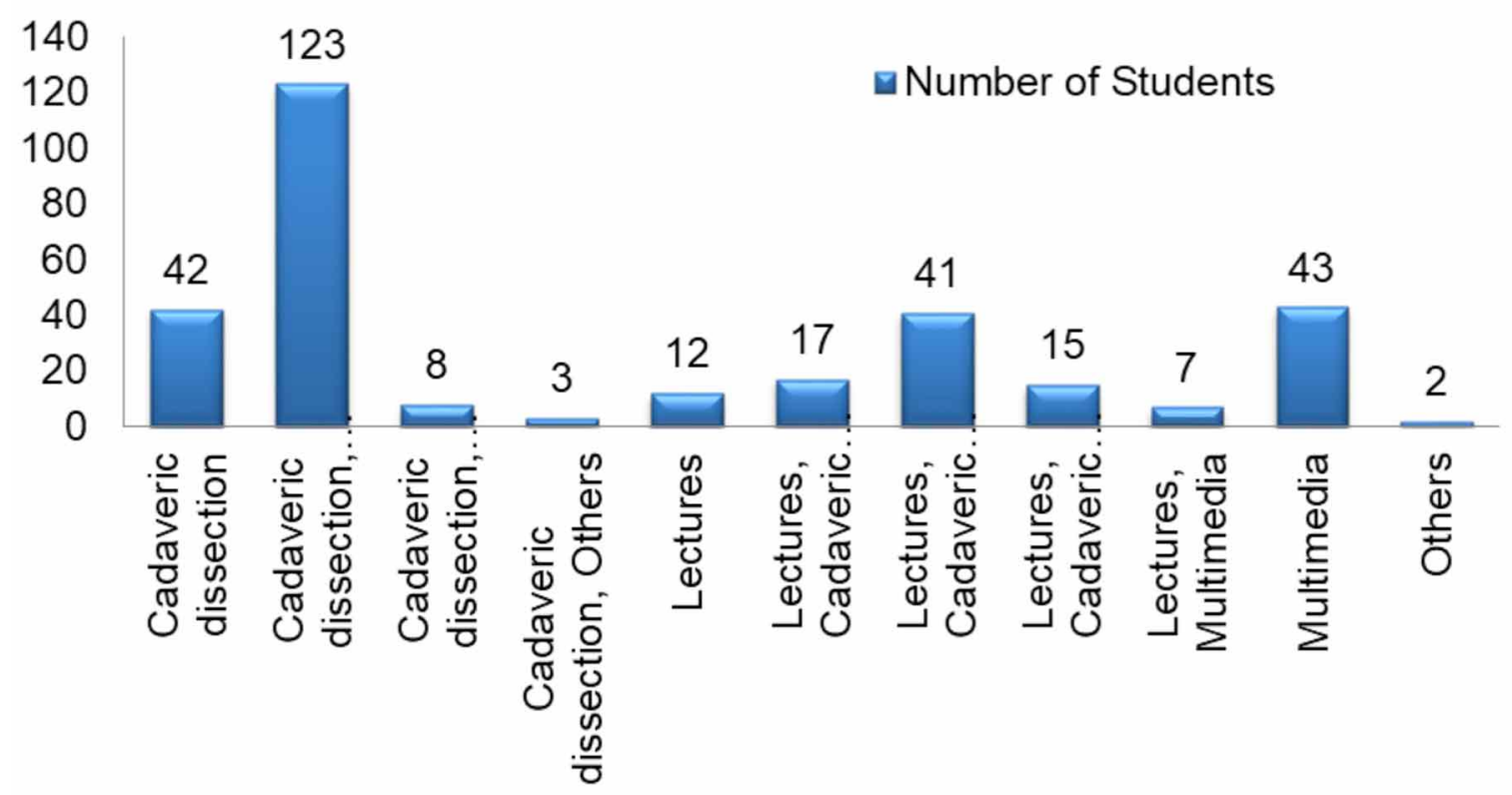

Fig. 2. In your opinion: Which method of teaching anatomy is best?

(13.1\%) supported the MCQ method alone and 28 students $(8.9 \%)$ preferred both methods together.

Students perception of their anatomy knowledge level was rather shocking demonstrating loss of confidence! Most students $86(27.5 \%)$ rated their level slightly above average (5 out of 8 ), whereas 14 students $(4.5 \%)$ rated their knowledge as 1 out of 8 and just 6 students (1.9\%) rated their knowledge as 8 out of 8 (Fig. 3).

The majority of students were not taught anatomy by surgeons in first 3 years of medical schools: 243 students $(77.6 \%)$ answered negatively and 70 students $(22.4 \%)$ said yes. Expectedly, students were in favor for being taught anatomy by surgeons in the first 3 years of medical schools: 98 students $(31.3 \%)$ said that they strongly support this suggestion and 27 students $(8.6 \%)$ were strongly disagree with this option. Most of the students support that anatomy should be taught by surgeons to improve their knowledge in Anatomy (Fig. 4).

In response to the question if the current anatomy teaching is adequate to understand the Laparoscopic view, radiology images, and endoscopic view respectively; most of the students were not satisfied by the currents methods of anatomy teaching (Fig. 5).

Finally, just 26 students $(28.3 \%)$ showed interest to pursue a career in anatomy or surgery / surgical subspecialties.

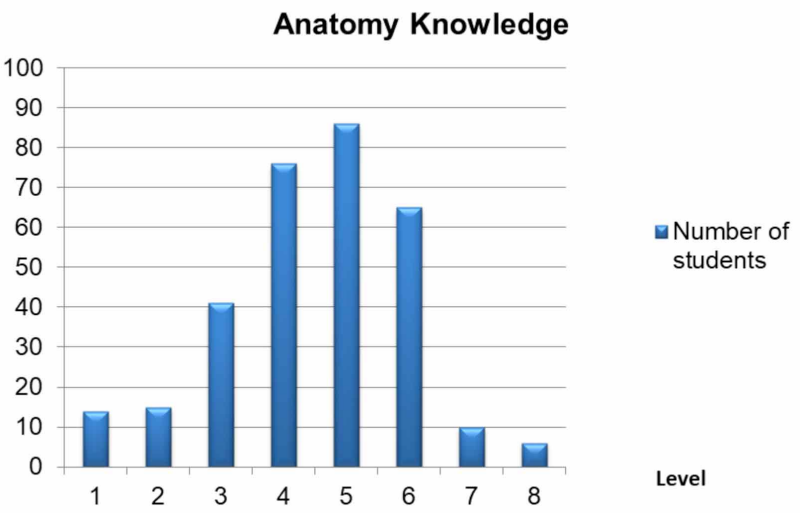

Fig. 3. How much would you assess your level of Anatomy Knowledge?

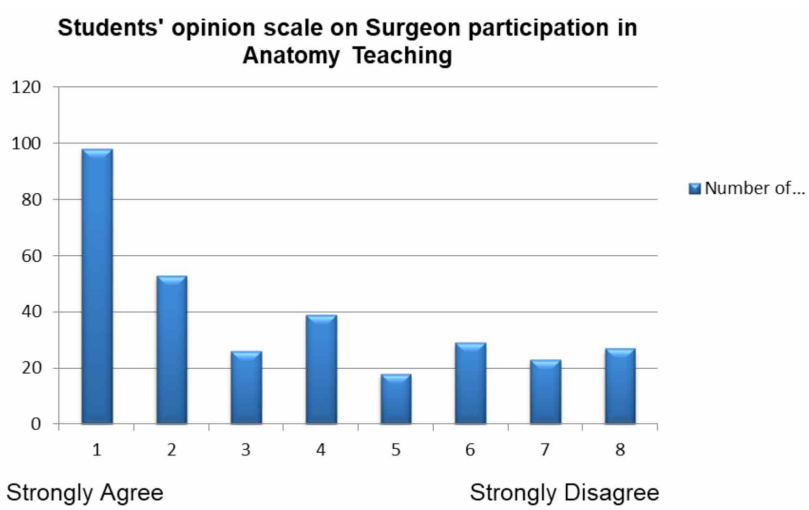

Fig. 4. Do you think that participation of Surgeons in the anatomy teaching in the first 3 years in the medical school useful / helps to improve the anatomy teaching? 


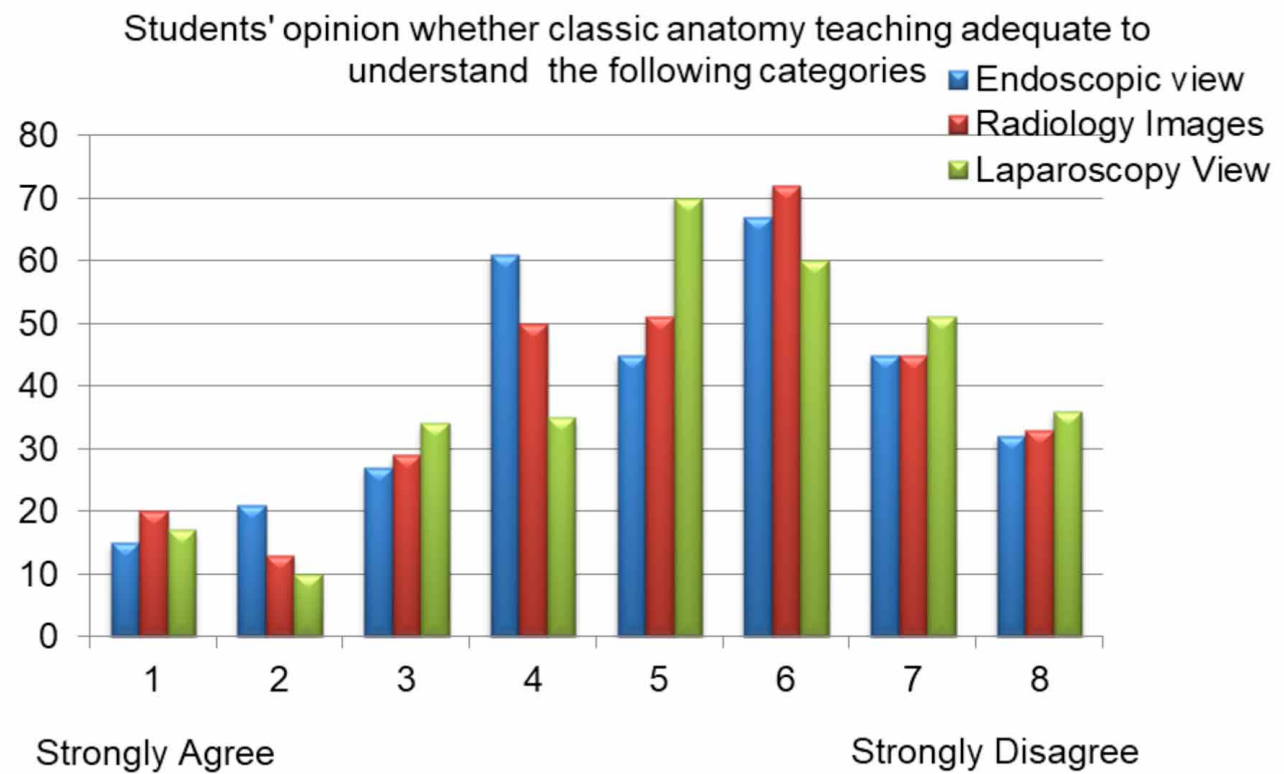

Fig. 5. Do you think that the current classical anatomy teaching is adequate to understand Endoscopic View, Radiology Images and Laparoscopy View?

\section{DISCUSSION}

This multi-center study is the first of it is kind in Jordan regarding the relevance and relationship between anatomy education and educational and clinical outcomes in association with the medical curriculum.

The results of the present study indicate that students have different perceptions of anatomy education and anatomical knowledge. We will discuss the results in light of the literature to arrive at implications for several areas of anatomy teaching.

Anatomy is a subject which is unique by its huge set of facts which is the base for all medical specialties. Giving the huge amount of information, anatomy needs a special way in teaching and delivering the information. Generally, there are two approaches in learning, the surface approach which depends on memorizing the information and deep approach which depends on understanding the given information by manipulating the information to make sense of them in relation to their meaning in the material. Many methods were used to teach anatomy. The majority of our students preferred cadaveric dissection in combination with multimedia because these methods potentially give an easier way to understand anatomy. They also provide visual and practical aids to relate the huge amount of information regarding the various anatomical structures which in comparison to the classical way only encourages the memorizing approach. These methods of teaching can also help to understand the relationship between anatomy and diseases (Norman, 2009).

Another important issue was the low confidence of students of using their knowledge of anatomy in clinical practice like reading the radiological images and understanding the endoscopic and laparoscopic views. This issue is a well recognized problem by the clinicians when they are involved in educating medical students. Yet, there is no formal educational strategy to overcome such a problem. In addition, students do not just need to memorize information but they need to learn how to apply information in clinical practice. Norman suggested strategies to enhance transfer, such as embedding a concept in a problem, encouraging active learning and mixed and distributed practice. Chariker et al. (2011) provided a good example and successful experience in using a combination of methods to teach neuro-anatomy which reflected in better learning, transfer, and retention of anatomical knowledge.

Finally, it is important to teach anatomy by surgeons as they could be the best personnel to teach medical students how to apply anatomical knowledge in clinical practice. Surgeons who teach anatomy by whole-body dissection are an extremely valuable and rare resource. They are essential to the provision of a clinical context to students. This was discussed by Burgess \& Ramsey-Stewart (2014) who discusses what motivates surgeons to teach dissection anatomy to medical students. 


\section{CONCLUSION}

Anatomy is one of the most important basic medical sciences. The results of this study showed that the approach of teaching should be changed to be the combination of multiple techniques specially cadaveric dissection and multimedia for better understanding of the information and therefore easier memorizing. In addition, medical schools are encouraged to utilize surgeons to teach anatomy which could help medical students learn how to translate their knowledge of anatomy into clinical practice .

TAYYEM, R.; QANDEEL, H.; QSOUS, G.; BADRAN, D. \& BANI-HANI, K. Percepción de estudiantes de medicina de la enseñanza actual de anatomía en el pregrado. Int. J. Morphol., 37(3):825-829, 2019.

RESUMEN: La anatomía es una de las ciencias básicas que forma parte de los primeros 3 años del currículo de enseñanza en las escuelas de medicina. El objetivo de esta encuesta fue explorar la percepción de los estudiantes de medicina en la enseñanza de la anatomía en diferentes escuelas de medicina e identificar los puntos débiles y el área en que podrían ayudar a mejorar el proceso de enseñanza con obtención de mejores resultados. Se realizó un estudio prospectivo multicéntrico, entre mayo de 2018 y agosto de 2018, aplicándose un cuestionario a 313 estudiantes de medicina en su año de pasantía y $6^{\circ}$ año. El cuestionario se envió a los estudiantes teniendo en cuenta la importancia de proteger la privacidad de los mismos. El cuestionario se elaboró después de una revisión exhaustiva de la literatura y sus ítems se seleccionaron luego de consultar con colegas médicos y educadores de alto nivel. El cuestionario se creó utilizando una escala de Likert de 8 elementos para imponer una respuesta y evitar una respuesta neutral. De los 313 estudiantes: 212 eran mujeres (67,7 $\%)$ y $101(32,3 \%)$ hombres; 123 estudiantes $(39,3 \%)$ apoyaron la combinación de disección de cadáveres y multimedia como mejores métodos de enseñanza. La mayoría de los estudiantes pensaron que los métodos clásicos de enseñanza pueden no ser muy útiles para comprender las imágenes radiológicas y las vistas intraoperatorias laparoscópicas. La mayoría de los estudiantes sugirió que involucrar a los cirujanos en la enseñanza de anatomía podría mejorar su conocimiento clínico en anatomía. Nuestros resultados mostraron que el enfoque de la enseñanza podría mejorarse combinando múltiples técnicas, especialmente la disección de cadáveres y las sesiones multimedia. Los resultados también indican que las escuelas de medicina deberían involucrar a los cirujanos en la enseñanza de la anatomía.

PALABRAS CLAVE: Enseñanza de anatomía; Estudiante de medicina; Cirujano; Percepción de la enseñanza por parte del estudiante.

\section{REFERENCES}

Alhassan, A. \& Majeed, S. Perception of Ghanaian medical students of cadaveric dissection in a problem-based learning curriculum. Anat. Res. Int., 2018:3868204, 2018.

Bandyopadhyay, R. \& Biswas, R. Students' perception and attitude on methods of anatomy teaching in a Medical College of West Bengal, India. J. Clin. Diagn. Res., 11(9):AC10-4, 2017.

Burgess, A. \& Ramsey-Stewart, G. What motivates surgeons to teach dissection anatomy to medical students and surgical trainees? Adv. Med. Educ. Pract., 6:11-6, 2014.

Chariker, J. H.; Naaz, F. \& Pani, J. R. Computer-based Learning of neuroanatomy: a longitudinal study of learning, transfer, and retention. $J$. Educ. Psychol., 103(1):19-31, 2011.

Choi-Lundberg, D. L.; Cuellar, W. A. \& Williams, A. M. Online dissection audio-visual resources for human anatomy: Undergraduate medical students' usage and learning outcomes. Anat. Sci. Educ., 9(6):545-54, 2016.

Eppler, E.; Serowy, S.; Link, K. \& Filgueira, L. Experience from an optional dissection course in a clinically-orientated concept to complement systembased anatomy in a reformed curriculum. Anat. Sci. Educ., 11(1):32-43, 2018.

Estai, M. \& Bunt, S. Best teaching practices in anatomy education: A critical review. Ann. Anat., 208:151-7, 2016.

Ghosh, S. K. Cadaveric dissection as an educational tool for anatomical sciences in the 21st century. Anat. Sci. Educ., 10(3):286-99, 2017.

Iqbal, H. Anatomy "Peer Teaching" in Medical School: A literature review. MedEdPublish, 5(2):6, 2016. Available from: https:// www.mededpublish.org/manuscripts/412

Kerby, J.; Shukur, Z. N. \& Shalhoub, J. The relationships between learning outcomes and methods of teaching anatomy as perceived by medical students. Clin. Anat., 24(4):489-97, 2011.

Norman, G. Teaching basic science to optimize transfer. Med. Teach., 31(9):80711, 2009.

Peterson, D. C. \& Mlynarczyk, G. S. Analysis of traditional versus three-dimensional augmented curriculum on anatomical learning outcome measures. Anat. Sci. Educ., 9(6):529-36, 2016.

Sbayeh, A.; Qaedi Choo, M. A.; Quane, K. A.; Finucane, P.; McGrath, D.; O'Flynn, S.; O'Mahony, S. M. \& O'Tuathaigh, C. M. Relevance of anatomy to medical education and clinical practice: perspectives of medical students, clinicians, and educators. Perspect. Med. Educ., 5(6):338-46, 2016.

Shiozawa, T.; Butz, B.; Herlan, S.; Kramer, A. \& Hirt, B. Interactive anatomical and surgical live stream lectures improve students' academic performance in applied clinical anatomy. Anat. Sci. Educ., 10(1):46-52, 2017.

Tayyem, R. The medical students perception of the undergraduate anatomy teaching survey: Hashemite University / Faculty of Medicine 2018. Google Forms, 2018. Available from: https://docs.google.com/forms/d/e/ 1 F A I p Q L S d 4 e 1 y Z P j u f A 5 V G S F t H K 4 V n V n HGPw5feeYI5AbVqERGLM7ag/viewform

Turney, B. W. Anatomy in a modern medical curriculum. Ann. R. Coll. Surg. Engl., 89(2):104-7, 2007.

\section{Corresponding author:}

Raed Tayyem

General surgery Department

Faculty of Medicine

Hashemite University

Al-Zarqa

JORDAN

Email: rtayyem@yahoo.com
Received: 09-12-2018

Accepted: 08-02-2019 